Ekspansi: Jurnal Ekonomi, Keuangan, Perbankan dan Akuntansi

ISSN (Online): 2580-7668 ISSN (Print): 2085-5230

Vol. 12, No. 2 (November 2020), Hal. 245 - 266

\title{
ANALISIS PENGARUH TINGKAT SUKU BUNGA, KUALITAS PELAYANAN INTI DAN KUALITAS PELAYANAN PERIFERAL TERHADAP KEPUTUSAN PENGGUNAAN FASILITAS PINJAMAN BANK BRI OLEH KARYAWAN PDAM CABANG BEKASI
}

\author{
Jessa Satia Anbiya ${ }^{1}$, Renny ${ }^{2}$ \\ ${ }^{1,2}$ Fakultas Manajemen, Universitas Gunadarma, Jakarta, Indonesia \\ Email Korespondensi: jessasatiaanbiya@gmail.com
}

\begin{abstract}
This research is a study that analyzes the effect of interest rates, core service quality and peripheral service quality on the decision to use BRI Bank loan facilities by employees of the Bekasi Branch PDAM. The population in this study were employees of the Regional Drinking Water Company in collaboration with the Bekasi Branch of BRI Bank. The size of the sample that could represent the population to be studied was 222 respondents. The method of analysis used is multiple regression. The data used are primary data with a research instrument in the form of a questionnaire. Based on the results of the research that has been done, it can be partially known that all existing independent variables, namely the variable interest rate, core service quality and peripheral service quality affect the existing independent variables, namely interest rate variables, core service quality and peripheral service quality affect positively and significant to the decision to use BRI Bank loan facilities, the results of the study also prove that the independent variable in this study is a clear explanation of the dependent variable.
\end{abstract}

Keywords: interest rate, core quality, quality of peripheral services and customer decision.

Abstrak: Penelitian ini merupakan studi yang melakukan analisis untuk mengetahui pengaruh tingkat suku bunga, kualitas pelayanan inti dan kualitas pelayanan periferal terhadap keputusan penggunaan fasilitas Pinjaman Bank BRI oleh Karyawan PDAM Cabang Bekasi. Populasi dalam penelitian ini adalah karyawan Perusahaan Daerah Air Minum yang bekerjasama dengan Bank BRI Cabang Bekasi, Besarnya sampel yang dapat mewakili populasi untuk diteliti adalah sebanyak 222 responden. Metode analisis yang digunakan adalah regresi berganda. Data yang digunakan merupakan data primer dengan instrumen penelitian berupa kuisioner. Berdasarkan hasil penelitian yang telah dilakukan, dapat diketahui secara parsial seluruh variabel bebas yang ada yaitu variabel tingkat suku bunga, kualitas pelayanan inti dan kualitas pelayanan periferal mempengaruhi variabel bebas yang ada yaitu variabel tingkat suku bunga, kualitas pelayanan inti dan kualitas pelayanan periferal mempengaruhi secara positif dan signifikan terhadap keputusan penggunaan fasilitas pinjaman Bank BRI, hasil penelitian juga membuktikan bahwa variabel bebas dalam penelitian ini merupakan penjelas nyata variabel terikatnya.

Kata Kunci: tingkat suku bunga, kualitas inti, kualitas pelayanan periferal dan keputusan pelanggan.

DOI: $10.35313 /$ ekspansi.v12i2.2085 


\section{PENDAHULUAN}

Keberadaan bank sebagai perusahaan yang bergerak di bidang keuangan memegang peranan sangat penting dalam memenuhi kebutuhan akan dana. Sehubungan dengan hal tersebut banyak pilihan bank saat ini, namun karakteristik bank dapat mempengaruhi perilaku calon nasabah dalam menentukan pemilihan suatu bank.

Saat ini bank terdapat beberapa pilihan produk pinjaman kepada nasabah nya diantaranya adalah Credit Card (CC), Kredit Tanpa Angunan (KTA), Kredit Kendaraan Bermotor (KKB) dan Kredit Pemilikan Rumah (KPR). Bank sebagai penyalur kredit merupakan alternatif bagi nasabah yang membutuhkan dana untuk beragam keperluan pribadi.

Seiring dengan bertambahnya kebutuhan pembiayaan seperti membeli rumah, merenovasi rumah, biaya pendidikan anak, biaya fasilitas kesehatan atau berobat, biaya persalinan, biaya pesta perkawinan, hingga membeli barang bergerak maupun tidak bergerak yang membutuhkan dana yang tidak sedikit maka pilihan fasilitas kredit pinjaman yang diberikan oleh bank menjadi solusi nya.

Berdasarkan survei Bank Indonesia tahun 2018 bahwa adanya penguatan permintaan kredit baru seperti terlihat dari saldo bersih tertimbang (SBT) permintaan kredit baru mencapai 94,3\% lebih tinggi dibanding kuartal tahun sebelumnya yang sebesar $77.9 \%$. Adapun permintaan kredit terjadi di semua jenis penggunaan kredit, hal tersebut tercermin dari SBT kredit modal kerja meningkat 13,2\% dibandingkan dengan kuarral sebelumnya menjadi $84,3 \%$, SBT kredit investasi yang naik $14,4 \%$ menjadi $84,2 \%$ dan SBT kredit konsumsi yang naik $14,5 \%$ menjadi $35 \%$.

Secara khusus, menguatnya pertumbuhan kredit konsumsi terutama didorong oleh meningkatnya permintaan Credit Card (CC), Kredit Pemilikan Rumah (KPR), Kredit Kendaraan Bermotor (KKB) dan Kredit Tanpa Angunan. Di sisi suku bunga, rata-rata suku bunga kredit turun seperti suku bunga kredit modal kerja turun 0,05\%, sementara suku bunga kredit konsumsi turun 0,08-0,10\%. Seiring perkembangan tersebut pertumbuhan kredit perbankan pada 2018 mencapai 11,89\% secara tahunan (year on year) atau lebih tinggi dibandingkan tahun 2017 yang pertumbuhannya kurang dari $10 \%$. Peningkatan pertumbuhan kredit konsumsi tercermin dari naiknya angka pertumbuhan penyaluran kredit perbankan kepada sektor kredit konsumsi.

Sesuai dengan tujuan yang dicapai indonesia dan untuk memenuhi kebutuhan masyarakat dan pemerataan dan pertumbuhan ekonomi negara (pemerintah) dan perbankan memberikan beberapa fasilitas kredit untuk masyarakat. Program fasilitas kredit ini dilaksanakan oleh bank yang mempunyai fungsi dan kegiatan utamanya adalah menghimpun dana dari masyarakat dan menyalurkan kembali kepada masyarakat dalam bentuk produk kredit. Hal tersebut sesuai dengan Undang-Undang No. 10 Tahun 1998 Tentang Perubahan atas Undang-Undang No. 7 Tahun 1992 Tentang Perbankan.

Masyarakat yang mempunyai kebutuhan dan membutuhkan biaya namun tidak mempunyai dana dapat memanfaatkan fasilitas kredit yang diberikan oleh bank salah satunya dengan mengadakan perjanjian Kredit Tanpa Angunan (KTA) dan tentunya 
telah memenuhi ketentuan yang dikeluarkan oleh bank. Bank Rakyat Indonesia (BRI) sebagai salah satu lembaga keuangan bank yang mempunyai fasilitas Kredit Tanpa Angunan yang dikenal dengan nama BRIGuna.

Kredit Tanpa Angunan salah satu pilihan solusi untuk kebutuhan konsumsi pribadi khususnya untuk karyawan tetap BUMN, BUMD, swasta dan pensiunan PNS. kelebihan KTA adalah plafon pinjaman sampai 500 juta, jangka waktu pinjaman panjang dan proses cepat.

Peningkatan pemberian Kredit Tanpa Angunan (KTA) disebabkan oleh meningkatnya kebutuhan masyarakat yang membutuhkan dana besar dan cepat perkembangan dari tahun ke tahun mengalami kenaikan, seperti yang diberikan oleh bank BRI dengan produk kredit BRIGuna, diperoleh informasi seperti pada Gambar 1.

\section{Kinerja Bank BUMN (Dalam Triliun Rupiah)}

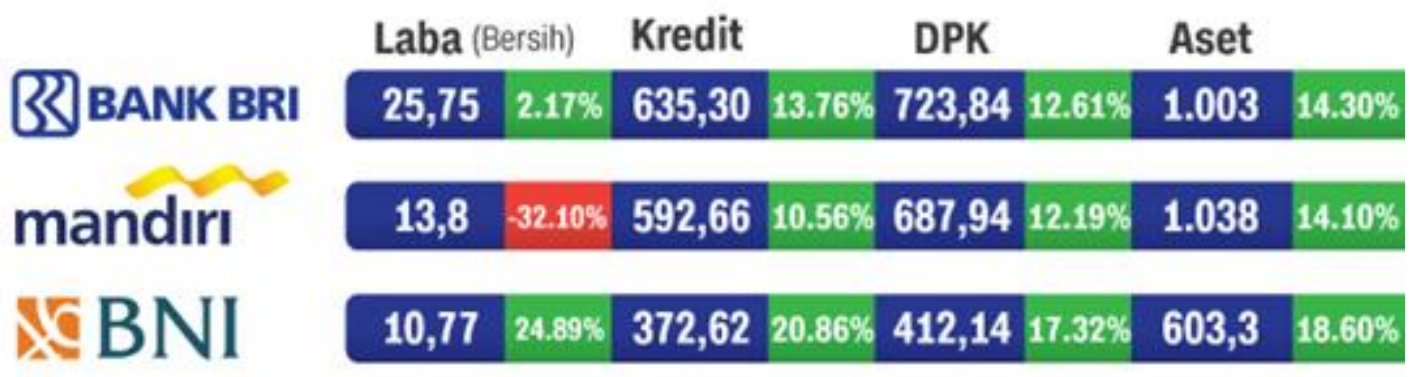

\section{Bank 回 BTN}

\section{$2,61 \quad 41.51 \% \quad 150,22 \quad 17.60 \% \quad 147,99 \quad 24.74 \% \quad 214,1 \quad 24.66 \%$}

Growth (yoy)

Naskah: Elisa Valenta Sari | Grafis: Fajrian

\section{Gambar 1}

Pertumbuhan Kinerja Bank BUMN 2018

Sumber : cnnindonesia (2019)

Berdasarkan gambar diatas, terlhat bahwa penyaluran kredit KTA BRIGuna milik Bank BRI mengalami peningkatan beserta fasilitas produk kredit yang lain, meskipun semakin banyaknya kompetitor Bank lain yang menawarkan KTA dengan fasilitas lebih menggiurkan bagi nasabah.

Kebutuhan sekunder terhadap konsumsi pribadi tersebut menciptakan peluang bisnis retail bagi perbankan dengan memberikan produk kredit bagi tiap individu nasabahnya. Produk kredit yang ditawarkan oleh bank dengan berbagai manfaat dan kelebihannya masing-masing menciptakan persaingan ketat, sehingga membuat bank berlomba-lomba untuk merebut calon debitur dengan berbagai jenis penawaran yang menarik.

Strategi untuk memenangkan persaingan dalam bisnis pinjaman kredit adalah suku bunga dan pelayanan yang kompetitif. Suku bungan pinjaman kredit yang tinggi menyebabkan ekspansi Bank tersebut menjadi turun. Pada sisi lain, Bank yang mampu 
memberikan pelayanan yang memuaskan, pasti dapat menarik banyak debitur sehingga mampu tumbuh dan berkembang.

Suku bunga kredit merupakan salah satu hal penting yang menjadi pertimbangan masyarakat sebelum mereka memutuskan untuk mengajukan pinjaman kredit pada bank maupun lembaga keuangan non bank. Menurut Teori penentuan tingkat suku bunga Keynes dikenal dengan teori liquidity prefence. Keynes mengatakan bahwa tingkat bunga semata-mata merupakan fenomena moneter yang mana pembentukannya terjadi di pasar uang. Artinya tingkat suku bunga ditentukan oleh penawaran dan permintaan akan uang.

Tjipto (2010) kualitas pelayanan adalah tingkat keunggulan yang diharapkan dan pengendalian atas tingkat keunggulan tersebut untuk memenuhi keinginan pelanggan. Berdasarkan pendapat di atas dapat disimpulkan bahwa ada factor utama yang mempengaruhi kualitas pelayanan yaitu: Jasa yang diharapkan dan jasa yang dirasakan. Apabila jasa yang dirasakan sesuai dengan jasa yang diharapkan, maka kualitas pelayanan tersebut akan dipersepsikan baik atau positif. Jika jasa yang dipersepsikan melebihi jasa yang diharapkan, maka kualitas jasa dipersepsikan sebagai kualitas ideal. Demikian juga sebaliknya apabila jasa yang dipersepsikan lebih jelek dibandingkan dengan jasa yang dipersepsikan negative atau buruk. Maka baik tidaknya kualitas pelayanan tergantung pada kemampuan penyedia jasa dalam memenuhi harapan konsumen secara konsisten.

Suku bunga kredit merupakan salah satu hal penting yang menjadi pertimbangan masyarakat sebelum mereka memutuskan untuk mengajukan kredit pada Bank maupun lembaga keuangan non bank. Teori Keynes menyatakan bahwa suku bunga kredit berhubungan positif dengan jumlah penawaran kredit, yang artinya peningkatan suku bunga kredit dapat meningkatkan jumlah penawaran kredit, namun sebaliknya peningkatan suku bunga kredit dapat menurunkan jumlah permintaan kredit. Kenaikan tingkat suku bunga akan mengurangi keinginan baik untuk pinjaman kredit konsumsi maupun berinvestasi, berikut ditampilkan tingkat suku bunga perbankan Nasional:

Tabel 1

Tingkat Suku Bunga Perbankan Nasional

\begin{tabular}{|c|l|c|}
\hline No & \multicolumn{1}{|c|}{ Bank } & Bunga (\%) \\
\hline 1 & Bank Rakyat Indonesia & 9,94 \\
\hline 2 & Bank Mandiri & 9,95 \\
\hline 3 & Bank Tabungan Negara & 11,25 \\
\hline 4 & Bank Negara Indonesia & 9,95 \\
\hline 5 & Bank Centra Asia & 9,75 \\
\hline 6 & Bank Panin & 10,18 \\
\hline 7 & Bank Danamon & 10,00 \\
\hline 8 & Bank CIMB Niaga & 9,60 \\
\hline 9 & Bank Maybank Indonesia & 9,00 \\
\hline 10 & Bank OCBC Nisp & 10,50 \\
\hline
\end{tabular}

Sumber: https://www.ojk.go.id/id, 2018 
Tabel 1 memperlihatkan tingkat suku bunga perbankan nasional, terlihat bahwa Bank BRI mempunyai tingkat suku bunga sebesar 9,94\% lebih tinggi dibandingkan Bank Maybank Indonesia (9,00\%) dan Bank CIMB Niaga (9,60\%) hal ini menjelaskan bahwa tingkat suku bunga bukan menjadi pertimbangan utama dalam keputusan menggunakan produk kredit suatu Bank, ini membuktikan bahwa walaupun produk dan harga yang ditawarkan oleh suatu Bank menarik, tanpa ada kualitas pelayanan yang baik tidak akan mampu memikat nasabah untuk melakukan keputusan untuk mengajukan kredit. Perbankan selalu memberikan pelayanan yang berkualitas yang secara langsung dapat dinilai oleh nasabah.

Perusahaan Daerah Air Minum Bekasi yang beralamat di Jl. Kalimalang BTb. 25 Kp. Tegal Danas, Ds. Hegarmukti, Kec. Cikarang Pusat, Kab. Bekasi, merupakan salah satu Perusahaan BUMD yang telah bekerja sama dengan salah satu Bank BUMN yaitu Bank BRI Kantor Cabang Bekasi yang beralamat di Jl. Ir. Juanda No. 93 Kota Bekasi, kerjasama itu meliputi Payroll gaji karyawan dan juga pinjaman khusus karyawan tetap. Besarnya kebutuhan pribadi karyawan yang memerlukan dana besar, pinjaman kredit Bank BRI adalah salah satu solusi selain pinjaman koperasi. Alasan lebih banyak memilih pinjaman bank BRI adalah plafon pinjaman yang besar dan suku bunga yang rendah. Berdasarkan observasi awal pada PDAM Bekasi, sering ditemukan keluhan karyawan karena pelayanan Bank BRI, salah satunya adalah antrian dan kecepatan proses pencairan. Antrian menyebabkan karyawan PDAM Bekasi harus menunggu lama sehingga membutuhkan kenyamanan saat mengantri, selain itu proses pencairan cukup membutuhkan waktu sehingga untuk menunggu pencairan setelah syarat proses terpenuhi sekitar 4- 8 minggu. Meskipun begitu staff Bank BRI mudah untuk diminta bantuan jika ada pertanyaan dan juga ramah sopan saat melayani nasabah. Berikut tabel yang menunjukan pengajuan fasilitas kredit Bank BRI oleh Karyawan PDAM Bekasi dari tahun 2016-2019:

\section{Tabel 2}

Pengajuan pinjaman kredit Bank BRI oleh karyawan PDAM Bekasi dari tahun 2016-2019

\begin{tabular}{|c|c|c|}
\hline Tahun & Bank BRI & Bank lain/Koperasi \\
\hline 2016 & 11 & 20 \\
\hline 2017 & 23 & 16 \\
\hline 2018 & 25 & 9 \\
\hline 2019 & 32 & 10 \\
\hline
\end{tabular}

Sumber: PDAM Tirta Bhagasasi Bekasi Bagian Sumber Daya Manusia, 2019

Terlihat pada Tabel diatas bahwa pada tahun 2016 sebanyak 11, sedangkan tahun 2017, 2018 dan 2019 mencapai 32 orang, hal ini mengalami peningkatan pengajuan kredit terhadap produk pinjaman kredit Bank BRI.

\subsection{Rumusan Masalah}

Berdasarkan latar belakang yang dipaparkan pada bab sebelumnya, maka rumusan masalah pada penelitian ini adalah Seberapa besar pengaruh tingkat suku bunga, kualitas pelayanan inti dan kualitas pelayanan periferal terhadap keputusan 
penggunaan fasilitas Pinjaman Bank BRI oleh Karyawan PDAM Cabang Bekasi baik secara simultan maupun parsial.

\subsection{Tujuan Penelitian}

Tujuan dari penelitian ini adalah untuk menganalisis seberapa besar pengaruh tingkat suku bunga, kualitas pelayanan inti dan kualitas pelayanan periferal terhadap keputusan penggunaan fasilitas Pinjaman Bank BRI oleh Karyawan PDAM Cabang Bekasi.

\subsection{Manfaat Penelitian}

a. Manfaat bagi peneliti

1) Sebagai bahan pertimbangan antara teori-teori yang diperoleh di bangku kuliah dengan kenyataan yang sebenarnya terjadi di lapangan dan pengembangan mengenai manajemen pemasaran.

2) Diharapkan dapat memberikan sumbangan ilmu pengetahuan di bidang manajemen perbankan, menjadi bahan kajian dan referensi bagi penelitian selanjutnya khusunya tentang tinkat suku bungan dan pelayanan kepada nasabah.

b. Manfaat bagi institusi

1) Bagi PDAM Cabang Bekasi, memberikan masukan dan pengaruh variabel-variabel yang dapat mempengaruhi keputusan nasabah serta memberikan saran terhadap

2) Bagi Bank BRI Cabang Bekasi

3) Penelitian ini dihaapkan menjadi masukan informasi tambahan bagi pihak-pihak yang berkepentingan terhadap pelayanan terhadap konsumen.

\section{TINJAUAN PUSTAKA}

Pengertian Bank secara sederhana dapat diartikan sebagai lembaga keuangan yang kegiatan usahanya menghimpun dana dari masyarakat dalam bentuk simpanan dan menyalurkan dana tersebut kepada masyarakat dalam bentuk kredit atau bentukbentuk lainnya dalam rangka meningkatkan taraf hidup rakyat banyak. Yang dimaksud dengan lembaga keuangan adalah setiap perusahaan yang bergerak di bidang keuangan dimana kegiatannya hanya menghimpun dan menyalurkan dana (Kasmir, 2012).

Namun definisi yang lain tentang bank adalah suatu badan yang menghimpun dana dari masyarakat dalam bentuk simpanan, dan menyalurkannya kepada masyarakat dalam bentuk kredit dan atau bentuk-bentuk lainnya dalam rangka meningkatkan taraf hidup rakyat banyak (Sentosa Sembiring, 2012 : 60).

Pengelompokkan bank di Indonesia secara umum dikelompokkan menjadi dua yaitu Bank Umum dan Bank Perkreditan Rakyat. Adapun penjelasan nya Bank Umum adalah bank yang melaksanakan kegiatan usaha secara konvensional dan atau berdasarkan Prinsip Syariah yang dalam kegiatannya memberikan jasa dalam lalu lintas pembayaran. Bank Perkreditan Rakyat adalah bank yang melaksanakan kegiatan usaha 
secara konvensional atau berdasarkan Prinsip Syariah yang dalam kegiatannya tidak memberikan jasa dalam lalu lintas pembayaran (Sentosa Sembiring, $2014: 4$ ).

Perbankan memang bukan merupakan satu-satunya sumber permodalan utama bagi investasi nasional dalam system perekonomian sekarang ini. Tetapi bagi Indonesia, perbankan merupakan sumber permodalan utama dan peranan itu masih relative besar dan diandalkan dibandingkan dengan pasar modal atau sumber permodalan lainnya.

Kredit berasal dari bahasa latin "credere" yang artinya percaya atau mempercayai (truth atau faith), karena memang pada dasarnya kredit diberikan berdasarkan kepercayaan orang/pihak lain yang memberikannya terhadap kecakapan dan kejujuran dari pihak pinjaman. Arti percaya tersebut dari segi bank sebagai pemberi kredit (kreditur) adalah bank percaya kepada nasabah sebagai penerima kredit bahwa pinjaman yang diberikan pasti akan dikembalikan sesuai dengan perjanjian. Sedangkan dari segi nasabah sebagai penerima kredit (debitur) adalah kepercayaan kepada bank sehingga memiliki kepercayaan untuk membayar tagihan sesuai dengan jangka waktu yang telah ditetapkan dalam perjanjian sebelumnya.

Dengan kata lain, kredit adalah penyediaan uang atau tagihan yang dapat dipersamakan dengan itu, berdasarkan persetujuan atau kesepakatan pinjammeminjam antara bank dengan pihak lain yang mewajibkan pihak peminjam untuk melunasi utangnya setelah jangka waktu tertentu dengan pemberian bunga (Sentosa Sembiring, $2014:$ 149).

Adapun alasan mengapa seseorang memerlukan kredit yaitu karena manusia adalah Homo Economicus yang dimana setiap manusia akan selalu berusaha untuk memenuhi kebutuhannya. Dengan sumber daya atau kemampuan yang dimiliki manusia yang terbatas untuk memenuhi kebutuhan atau keinginan yang tidak terbatas, hal ini menyebabkan manusia memerlukan bantuan modal untuk memenuhi kebutuhan atau keinginannya yang tak terbatas.

Pemberian suatu fasilitas kredit mempunyai tujuan tertentu. Tujuan pemberian kredit tersebut tidak akan terlepas dari misi bank tersebut didirikan. Adapun tujuan utama pemberian suatu kredit Kasmir adalah Mencari Keuntungan, Membantu Nasabah dan Membantu Pemerintah (Kasmir 2013 : 94).

Suku bunga kredit adalah harga atau biaya dari penggunaan dana yang tersedia untuk dipinjamkan. Suku bunga kredit berhubungan negative terhadap permintaan kredit. Artinya semakin tinggi suku bunga kredit yang mencerminkan semakin mahalnya biaya yang akan dikeluarkan oleh nasabah maka akan menurunkan permintaan kredit, dan sebaliknya semakin rendah suku bunga kredit yang mencerminkan murahnya biaya yang akan meningkatkan permintaan kredit.

Penelitian yang dilakukan oleh Siwi (2019) dengan judul Analisis Pengaruh Tingkat Suku Bunga terhadap Permintaan Kredit pada Bank Umum di Indonesia tahun 2011-2017. Hasil penelitian menunjukkan bahwa variabel Tingkat Suku Bunga berpengaruh negatif dan signifikan terhadap Permintaan Kredit pada Bank Umum di Indonesia 
H1 : tingkat suku bunga kredit berpengaruh terhadap keputusan dalam penggunaan fasilitas kredit di Bank BRI.

Pelanggan merupakan focus utama dalam bisnis, karena tanpa pelanggan perusahaan tidak bisa memperoleh profit untuk menjalankan usahanya. Oleh karena itu, hal utama yang harus dilakukan adalah dengan memberikan pelayanan yang berkualitas sehingga tercipta kepuasan untuk mendapatkan pelanggan yang loyal pada perusahaannya. Dalam penelitian ini kualitas inti di tentukan berdasarkan proses pengajuan kredit nasabah pada BANK BRI.

Adapun penelitian yang dilakukan oleh Badrul Huda, dkk (2019) dengan judul Pengaruh Kualitas Pelayanan, Prosedur Kredit dan Tingkat Suku Bunga terhadap Keputusan Nasabah dalam Mengambil Kredit pada PT Bank Perkreditan Rakyat Sukowono Arthajaya Jember. Hasil penelitian menyatakan bahwa kualitas pelayanan, prosedur kredit, dan tingkat suku bungaberpengaruh signifikan sebesar 82,1\%terhadap keputusan nasabah dalam pengambilan kredit pada PT. Bank Perkreditan Rakyat Sukowono Arthajaya Jember.Prosedur kredit berpengaruh dominan terhadap keputusan nasabah dalam pengambilan kredit pada PT. Bank Perkreditan Rakyat Sukowono Arthajaya Jember sebesar 41,9\%, sedangkan sumbangan pengaruh untuk kualitas pelayanan sebersar $17,3 \%$ dan tingkat suku bunga sebesar $22,9 \%$.

H2 : Kualitas Pelayanan Inti berpengaruh terhadap keputusan nasabah dalam pengambilan kredit di Bank BRI.

Kualitas Periperal merupakan penilaian konsumen terhadap suatu kualitas yang menyebabkan suatu barang atau jasa menjadi pilihan dan menjadi kualitas pendukung, sepeti : Fasilitas dan Lokasi.

Adapun penelitian yang dilakukan Oleh Adhitya pada tahun 2013 dengan judul Analisis Pengaruh Suku Bunga Kredit, Kualitas Pelayanan Inti, Kualitas Periferal dan Kemampuan Tenaga Marketing terhadap Keputusan Nasabah dalam Pengambilan Kredit di Bank Mandiri Unit Mikro Distrik Semarang. Berdasarkan hasil pengujian hipotesis, maka terdapat beberapa implikasi manajerial yang dapat dilakukan berkaitan dengan peningkatan keputusan nasabah dalam pengambilan kredit, yaitu: peran aktif dari staf marketing dan analis kredit untuk mendukung kecepatan proses kredit, perbaikan dan pengembangan fasilitas penunjang yang mendukung bagi kelancaran kredit yang dibutuhkan nasabah, menetapkan suku bunga kredit di level 1\% atau suku bunga yang sebanding dengan suku bunga pesaing, training yang berkelanjutan dan motivasi-motivasi dari atasan perlu untuk tetap dilakukan.

H3 : Kualitas Pelayanan Periferal berpengaruh terhadap keputusan nasabah dalam pengambilan kredit di Bank BRI.

\section{METODE PENELITIAN}

Jenis penelitian merupakan cara peneliti yang digunakan dalam mendapatkan data untuk mencapai tujuan tertentu. Sugiyono (2013) metode penelitian pada dasarnya merupakan cara ilmiah untuk mendapatkan data dengan tujuan dan kegunaan 
tertentu, dan penelitian itu didasarkan pada ciri - ciri keilmuan yaitu rasional, empiris dan sistematis. Dalam penelitian ini, penulis menggunakan penelitian asosiatif atau penelitian berdasarkan hubungan yang bertujuan untuk mengetahui antar dua variable atau lebih dan penelitian ini mempunyai hubungan kausal (sebab-akibat) antara variable independen. Penelitian ini menggunakan rancangan penelitian kausalitas yang bertujuan untuk memahami variable yang mempengaruhi (independen) dan variable yang merupakan akibat (dependen) serta menentukan sifat antara variabel independen dan pengaruh yang diperkirakan.

Penelitian ini menggunakan data primer yang berasal dari karyawan PDAM Bekasi yang mengajukan fasilitas kredit melalui bank BRI Cabang Bekasi sebagai subjek penelitian.

Variabel adalah suatu atribut atau sifat atau nilai dari orang, objek, atau kegiatan yang mempunyai variasi tertentu yang ditetapkan oleh peneliti untuk dipelajari dan ditarik kesimpulannya. Variabel penelitian ini terdiri atas 2 jenis, yaitu variabel bebas (independent variabel), variabel terikat (dependent variabel). Variabel bebas dalam hal ini adalah variabel yang menjadi penyebab terjadinya atau memberi pengaruh terhadap variabel terikat.

Penelitian ini menggunakan dua variabel yaitu :

a. Variabel dependen

Variabel dependen adalah variabel yang menjadi pusat perhatian utama peneliti. Hakekat sebuah masalah mudah terlihat dengan mengenali berbagai variabel dependen yang digunakan dalam sebuah model. Sugiyono dalam Zulfikar (2016), variabel dependen adalah variabel yang mempengaruhi atau dikenal juga sebagai variabel yang menjadi akibat karena adanya variabel independen. Selanjutnya Widiyanto (2013), menjellaskan bahwa variabel dependen adalah variabel yang keberadaannya dipengaruhi oleh variabel lain.

variabel dependen adalah : Keputusan Pengambilan Kredit (Y).

b. Variabel Independen

Variabel independen yang dilambangkan dengan (X) adalah variabel yang mempengaruhi atau yang menjadi sebab perubahan atau timbulnya variabel dependen (terikat) (Sugiyono, 2010). Selanjutnya Widiyanto (2013) variabel independen merupakan variabel yang mempengaruhi variabel lainnya.

Variabel independen dalam penelitian ini adalah :

- Suku Bunga (X1)

- Kualitas Pelayanan Inti (X2)

- Kualitas Pelayanan Periferal (X3)

Populasi dalam penelitian ini adalah seluruh karyawan PDAM Bekasi yang menggunakan fasilitas kredit Bank BRI, data diperoleh mmelalui kuesioner tentang keputusan nasabah dalam pengambilan kredit mikro, adapun responden yang digunakan dalam penelitian adalah 222 responden.

Pedoman dalam menentukan ukuran sampel yang dipergunakan yaitu lima sampai sepuluh kali jumlah indikator penelitian (Ferdinand, 2011:48). Berdasarkan 
pandangan tersebut, maka sampel yang ditetapkan dalam penelitian ini sebesar 222 responden.

\section{HASIL DAN PEMBAHASAN}

Hasil analisis deskriptif jawaban responden pada setiap indikator variabel Tingkat suku bunga disajikan pada tabel 3berikut:

\section{Tabel 3}

Distribusi Jawaban Responden pada Kuesioner Tingkat Suku Bunga

\begin{tabular}{|c|c|c|c|c|c|c|c|c|c|c|c|c|}
\hline \multirow{3}{*}{ Item } & \multicolumn{10}{|c|}{ Jawaban } & \multirow{3}{*}{ Jumlah } & \multirow{3}{*}{$\begin{array}{l}\text { Mean } \\
\text { item }\end{array}$} \\
\hline & \multicolumn{2}{|c|}{ (1) STS } & \multicolumn{2}{|c|}{ (2) TS } & \multicolumn{2}{|c|}{ (3) CS } & \multicolumn{2}{|c|}{ (4) $S$} & \multicolumn{2}{|c|}{ (5) SS } & & \\
\hline & $F$ & $\%$ & $F$ & $\%$ & $F$ & $\%$ & $F$ & $\%$ & $F$ & $\%$ & & \\
\hline X1_1 & 0 & $0 \%$ & 2 & $1 \%$ & 28 & $13 \%$ & 70 & $32 \%$ & 122 & $55 \%$ & 222 & 4,41 \\
\hline $\mathrm{X} 12$ & 0 & $0 \%$ & 5 & $2 \%$ & 17 & $8 \%$ & 80 & $36 \%$ & 120 & $54 \%$ & 222 & 4,42 \\
\hline X1_3 & 0 & $0 \%$ & 2 & $1 \%$ & 10 & $5 \%$ & 96 & $43 \%$ & 114 & $51 \%$ & 222 & 4,45 \\
\hline X1_4 & 1 & $0 \%$ & 0 & $0 \%$ & 13 & $6 \%$ & 90 & $41 \%$ & 118 & $53 \%$ & 222 & 4,46 \\
\hline X1_5 & 0 & $0 \%$ & 2 & $1 \%$ & 16 & $7 \%$ & 89 & $40 \%$ & 115 & $52 \%$ & 222 & 4,43 \\
\hline Total & 1 & $0 \%$ & 11 & $1 \%$ & 84 & $8 \%$ & 425 & $38 \%$ & 589 & $53 \%$ & 1110 & 4,43 \\
\hline
\end{tabular}

Sumber: Data diolah, 2020

Berdasarkan tabel di atas, terlihat bahwa jawaban responden mengarah pada jawaban Setuju (38\%). Hasil analisis rata-rata keseluruhan jawaban responden pada variabel Tingkat suku bungaadalah sebesar 4,43. Indikator Tingkat suku bungatertinggi diperoleh pada item X1_4 yaitu (rata-rata 4,46) dan indikator terendah adalah item X1_1 yaitu (rata-rata 4,41).

Pengujian normalitas data dalam penelitian ini menggunakan normal probability Plot yang membandingkan distribusi komulatif dari distribusi normal. Jika distribusi data normal maka garis yang menggambarkan data sesungguhnya akan mengikuti garis diagonalnya (Ghozali, 2011). Hasil uji normalitas data penelitian ini dapat dilihat pada grafik berikut:

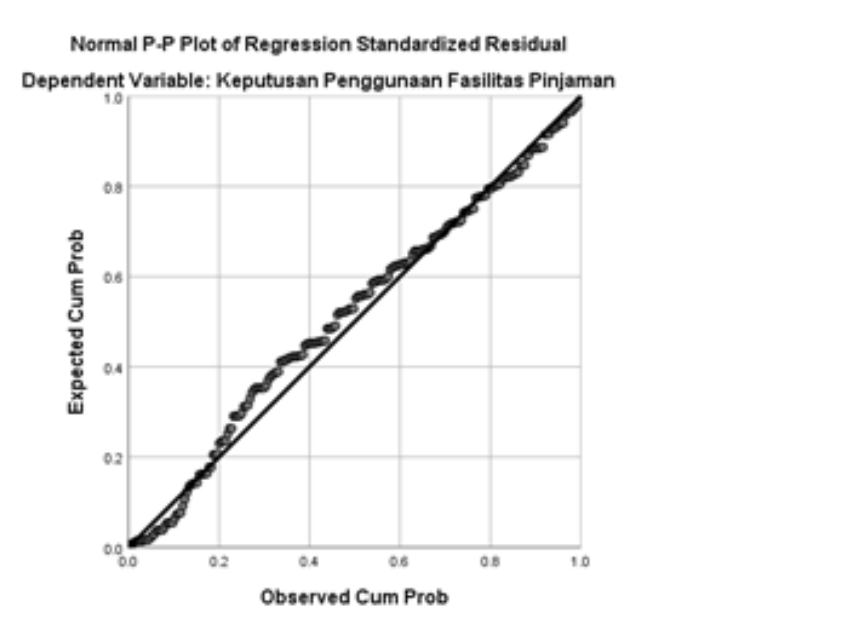

Gambar 2

Grafik Distribusi Normal Data Residual 
Berdasarkan Gambar di atas, dapat diketahui bahwa plot data mengikuti garis diagonalnya. Dengan demikian dapat dinyatakan bahwa data dalam penelitian ini mengikuti distribusi normal. Hal ini diperkuat hasil uji statistik Kolmogrov-Smirnov sebagai berikut:

\section{Tabel 4}

Uji Statistik Normalitas Data Residual dengan Uji Kolmogrov-Smirnov One-Sample Kolmogorov-Smirnov Test

\begin{tabular}{llr}
\hline $\mathrm{N}$ & & Unstandardized Residual \\
\hline Normal Parameters & & 222 \\
\cline { 2 - 3 } & Mean & .0000000 \\
\cline { 2 - 3 } & Std. Deviation & 1.41839450 \\
\hline Most Extreme Differences & Absolute & .077 \\
\cline { 2 - 3 } & Positive & .046 \\
\cline { 2 - 3 } & Negative & .077 \\
\hline Test Statistic & & .149 \\
\hline Asymp. Sig. (2-tailed) & & .143 \\
\hline
\end{tabular}

a. Test distribution is Normal.

Data mengikuti distribusi normal apabila nilai signifikansi pengujian KolmogorovSmirnov (K-S) lebih besar dari taraf signifikansi 0,05 (Ghozali, 2011). Hasil uji normalitas terlihat nilai stastistik K-S sebesar 1,149 dan signifikansi sebesar 0,143 > 0,05 , sehingga dapat disimpulkan bahwa data residual memiliki distribusi normal.

\subsection{Uji Heterokedastisitas}

Uji Heteroskedastisitas bertujuan untuk mengetahui apakah dalam model regresi terjadi kesalahan atau ketidaksamaan variance dari residual suatu pengamatan ke pengamatan lain. Untuk menguji adanya gejala heteroskedastisitas digunakan pengujian dengan metode scatter plot, dengan kriteria hasil sebagai berikut:

a. Jika pola tertentu seperti titik-titik yang ada membentuk suatu pola yang teratur (bergelombang, melebar kemudian menyempit) maka telah terjadi heteroskedastisitas.

b. Jika tidak ada yang jelas serta titik-titik menyebar di atas dan di bawah angka nol pada sumbu Y maka tidak terjadi heteroskedastisitas.

c. Hasil uji heterokedastisitas dapat dilihat pada grafik berikut:

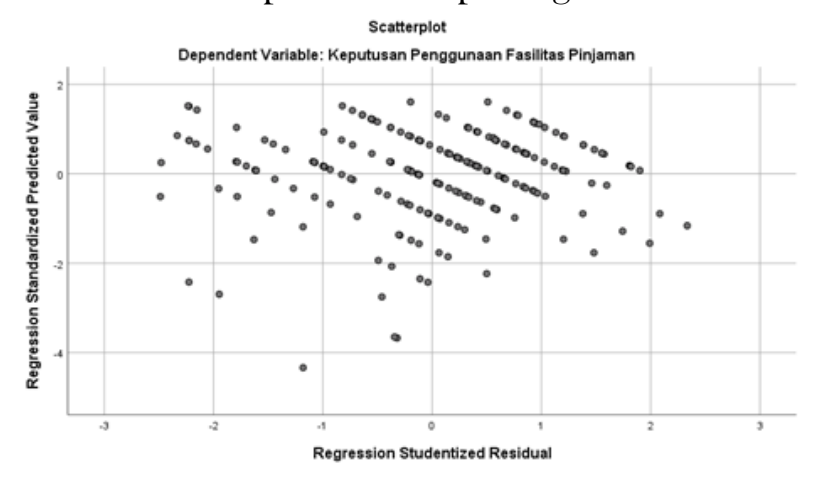

Gambar 3

Grafik Hasil Uji Heteroskedasitas 
Berdasarkan gambar 3 scater plot di atas, diketahui titik-titik yang diperoleh menyebar secara acak dan tidak membentuk suatu pola tertentu atau menyebar di atas dan di bawah angka nol pada sumbu Y, sehingga dapat disimpulkan bahwa pada data yang diteliti tidak ditemukan masalah.

\subsection{Uji Multikolinieritas}

Multikolinearitas menunjukkan adanya lebih dari satu hubungan linier yang sempurna. Ghozali (2011) bahwa tujuan uji multikolinearitas adalah untuk menguji apakah pada model regresi ditemukan adanya korelasi antar variabel independent.Apabila terjadi korelasi, maka dinamakan terdapat masalah multikolinearitas. Mendeteksi adanya multikolinearitas adalah dari besarnya VIF (Variance Inflating Factor) dan tolerance. Pedoman suatu model regresi yang bebas multikolinearitas Ghozali (2011) adalah:

a. Mempunyai nilai VIF $\leq 10$

b. Mempunyai angka tolerance $\geq 0,10$.

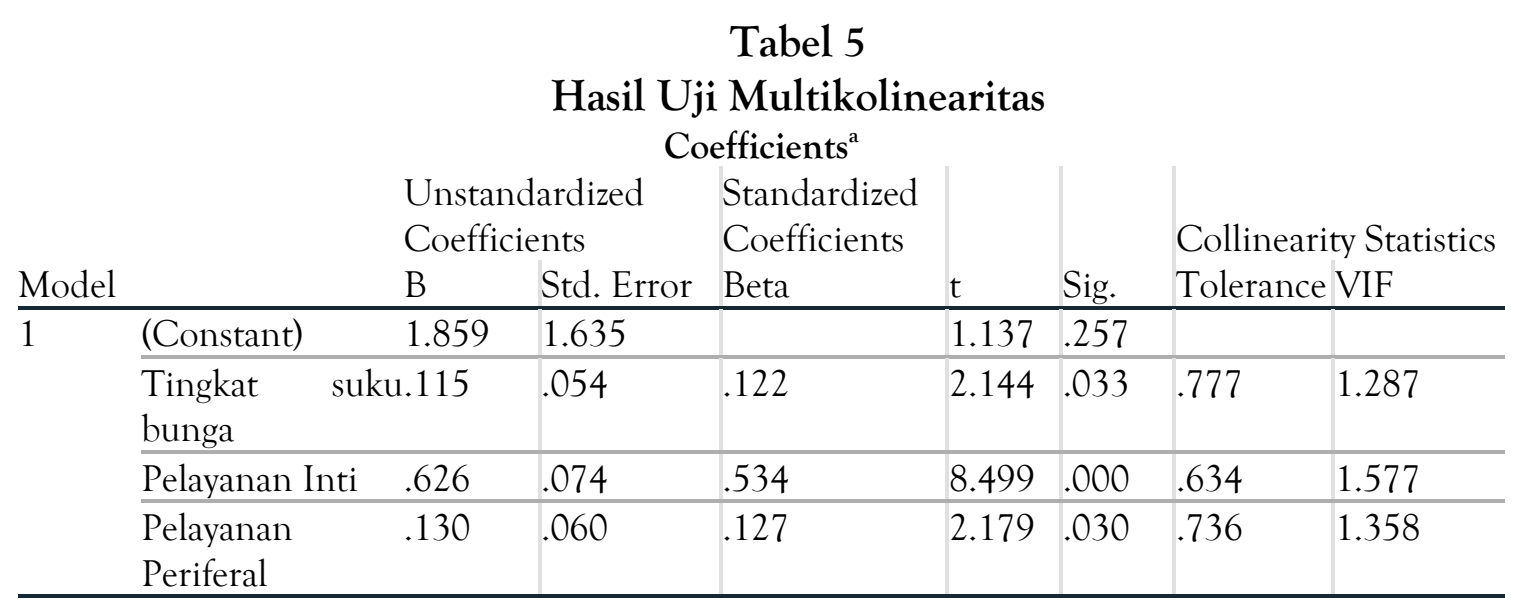

a. Dependent Variable: Keputusan Penggunaan Fasilitas Pinjaman

Berdasarkan hasil pengolahan, diketahui bahwa variabel bebas Tingkat suku bunga, Pelayanan Inti, Pelayanan Periferal memiliki nilai tolerance masing-masing lebih besar dari 0,10 dan nilai VIF kurang dari 10, sehingga dapat disimpulkan bahwa dalam model regresi tersebut tidak terjadi multikolinieritas.

\subsection{Hasil Regresi Berganda}

Penelitian ini menggunakan teknik analisis regresi linier berganda dengan variabel bebas (independen) adalah Tingkat suku bunga (X1), Pelayanan Inti (X2) dan Pelayanan Periferal (X3). Variabel dependen dalam penelitian ini yakni Keputusan Penggunaan Fasilitas Pinjaman (Y). Berdasarkan pengolahan data yang dilakukan dengan menggunakan software SPSS 26 didapatkan hasil analisis sebagai berikut: 
Tabel 6

Hasil Analisis Regresi Berganda

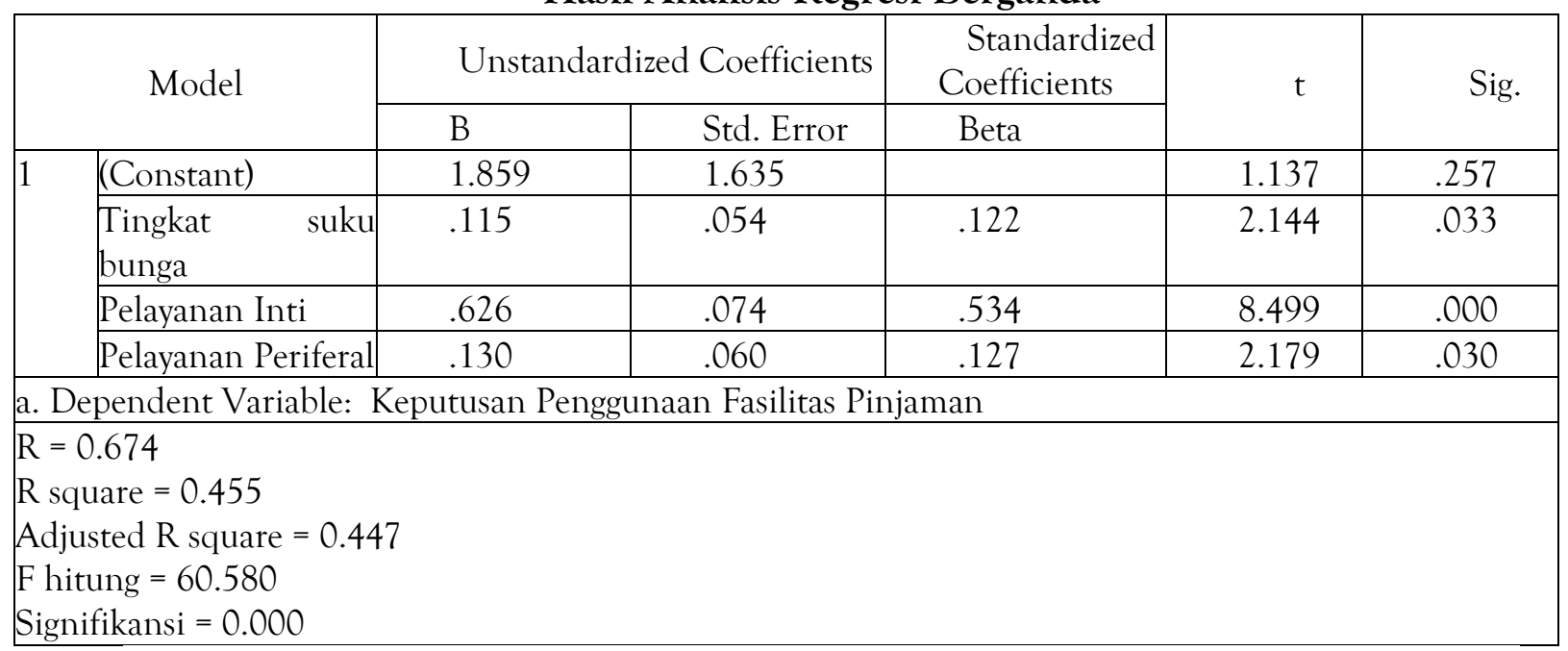

Berdasarkan data yang disajikan pada tabel di atas maka dapat ditemukan bentuk hasil estimasi model dapat ditulis dalam persamaan di bawah ini:

$\mathrm{Y}=1,859+0,115 \mathrm{TSB}+0,626 \mathrm{PI}+0,130 \mathrm{PP}$

Adapun asumsi dari persamaan yang terdapat pada tabel di atas yaitu :

1. Nilai konstanta adalah sebesar 1,859 Dapat dijelaskan bahwa Keputusan Penggunaan Fasilitas Pinjaman sebelum adanya variabel independen yaitu Tingkat suku bunga (X1), Pelayanan Inti (X2), Pelayanan Periferal (X3) adalah sebesar 1,859 satuan

2. Nilai koefisien regresi variabel Tingkat suku bunga $(\mathrm{X} 1)=0,115$ menunjukkan bahwa apabila setiap variabel Tingkat suku bunga mengalami peningkatan 1 satuan maka akan berdampak pada peningkatan Keputusan Penggunaan Fasilitas Pinjaman sebesar 0,115 satuan dengan asumsi variabel yang lain tetap atau tidak mengalami perubahan.

3. Nilai koefisien regresi variabel Pelayanan Inti $(X 2)=0,626$, menunjukkan bahwa apabila setiap variabel Pelayanan Inti mengalami peningkatan 1 satuan maka akan berdampak pada peningkatan Keputusan Penggunaan Fasilitas Pinjaman sebesar 0,626 satuan dengan asumsi variabel yang lain tetap atau tidak mengalami perubahan.

4. Nilai koefisien regresi variabel Pelayanan Periferal $(X 3)=0,130$, menunjukkan bahwa apabila setiap variabel Pelayanan Inti mengalami peningkatan 1 satuan maka akan berdampak pada peningkatan Keputusan Penggunaan Fasilitas Pinjaman sebesar 0,130 satuan dengan asumsi variabel yang lain tetap atau tidak mengalami perubahan.

\subsection{Uji Parsial (Uji t)}

Uji parsial atau uji $t$ merupakan pengujian dari masing-masing variabel bebas terhadap variabel terikat.Variabel bebas (independen) dikatakan memiliki pengaruh signifikan jika nilai probabilitas atau signifikasi hasil penghitungan lebih kecil daripada $\alpha=0,05$. Sebaliknya apabila signifikasi lebih besar daripada $\alpha=0,05$, maka variabel 
bebas (independen) tidak berpengaruh yang signifikan terhadap variabel dependen. Berdasarkan Tabel hasil analisis regresi berganda di atas dapat mengetahui pengaruh variabel secara parsial sebagai berikut:

1) Pengaruh variabel Tingkat suku bunga (X1) terhadap Keputusan Penggunaan Fasilitas Pinjaman.

Berdasarkan hasil olahan data diperoleh nilai thitung sebesar 2,144 dan nilai signifikansi sebesar 0,033. Oleh karena nilai signifikasi sebesar 0,033<0,05, maka dapat disimpulkan bahwa Tingkat suku bunga berpengaruh terhadap Keputusan Penggunaan Fasilitas Pinjaman.Koefisien regresi bernilai positif menunjukkan bahwa pengaruh Tingkat suku bunga terhadap Keputusan Penggunaan Fasilitas Pinjaman bersifat positif.Dengan demikian hipotesis pertama yang menyatakan bahwa Tingkat suku bunga berpengaruh terhadap Keputusan Penggunaan Fasilitas Pinjaman, dapat diterima.

2) Pengaruh variabel Pelayanan Inti (X2) terhadap Keputusan Penggunaan Fasilitas Pinjaman.

Berdasarkan hasil olahan data diperoleh nilai thitung sebesar 8,499 dan nilai signifikansi sebesar 0,000. Oleh karena nilai signifikasi sebesar 0,000 < 0,05, maka dapat disimpulkan bahwa Tingkat suku bunga berpengaruh terhadap Keputusan Penggunaan Fasilitas Pinjaman.Dengan demikian hipotesis kedua yang menyatakan bahwa Pelayanan Inti berpengaruh terhadap Keputusan Penggunaan Fasilitas Pinjaman, diterima.

3) Pengaruh variabel Pelayanan Periferal (X3) terhadap Keputusan Penggunaan Fasilitas Pinjaman.

Berdasarkan hasil olahan data diperoleh nilai thitung sebesar 2,179 dan nilai signifikansi sebesar 0,030. Oleh karena nilai signifikasi sebesar 0,030<0,05, maka dapat disimpulkan bahwaPelayanan Periferal berpengaruh terhadap Keputusan Penggunaan Fasilitas Pinjaman.Koefisien regresi bernilai positif menunjukkan bahwa pengaruh Pelayanan Periferal terhadap Keputusan Penggunaan Fasilitas Pinjaman bersifat positif.Dengan demikian hipotesis ketiga yang menyatakan bahwa Pelayanan Periferal berpengaruh terhadap Keputusan Penggunaan Fasilitas Pinjaman, dapat diterima.

\subsection{Uji Simultan (Uji F)}

Pengujian hipotesis uji $\mathrm{F}$ digunakan untuk melihat apakah secara keseluruhan variabel bebas mempunyai pengaruh yang bermakna terhadap variabel terikat. Dari hasil pengujian regresi menunjukkan pengujian simultan diperoleh dari hasil pengolahan data menunjukkan nilai $\mathrm{F}$ hitung sebesar 60,580 dan nilai probabilitas signifikansi tersebut sebesar 0,000 dan tingkat $\alpha$ sebesar $5 \%$, hal ini menunjukkan bahwa nilai signifikansi uji F 0,000 lebih kecil daripada nilai signifikansi 0,05. Artinya bahwa Tingkat suku bunga (X1), Pelayanan Inti (X2), dan Pelayanan Periferal (X3) merupakan penjelas nyata terhadap Keputusan Penggunaan Fasilitas Pinjaman. Dengan kata lain dapat dikatakan model layak digunakan dalam penelitian. 


\subsection{Uji Koefisien Determinasi $\left(\mathrm{R}^{2}\right)$}

Uji Koefisien Determinasi $\left(\mathrm{R}^{2}\right)$ atau kontribusi pengaruh. Besar pengaruh masingmasing variabel bebas dapat dapat diketahui dari perkalian antara koefisien beta dengan korelasi zero-order (korelasi product moment).

Tabel 7

Kontribusi Pengaruh

\begin{tabular}{|l|l|l|l|}
\hline Variabel & Koefisien beta & $\begin{array}{l}\text { Korelasi } \\
\text { product } \\
\text { moment }\end{array}$ & $\begin{array}{l}\text { Besar } \\
\text { pengaruh }\end{array}$ \\
\hline $\begin{array}{l}\text { Tingkat suku } \\
\text { bunga }\end{array}$ & 0.122 & 0.409 & 0.050 \\
\hline Pelayanan Inti & 0.534 & 0.655 & 0.350 \\
\hline $\begin{array}{l}\text { Pelayanan } \\
\text { Periferal }\end{array}$ & 0.127 & 0.435 & 0.055 \\
\hline & & Total & 0.455 \\
\hline
\end{tabular}

Sumber : Data diolah, 2020

Pada tabel Model Summary diketahui nilai $\mathrm{R}$ Square $=0,455$, artinya pengaruh Tingkat suku bunga, Pelayanan Inti, Pelayanan Periferal, secara simultan terhadap Keputusan Penggunaan Fasilitas Pinjaman sebesar 45,5\%. Nilai tersebut terdiri dari kontribusi Tingkat suku bunga sebesar 5,0\%; kontribusi Pelayanan Inti sebesar 35,0\%; kontribusi Pelayanan Periferal sebesar 5,5\%.

\subsection{Pembahasan}

\subsubsection{Pengaruh Tingkat suku bunga terhadap Keputusan Penggunaan Fasilitas Pinjaman}

Penelitian ini memperoleh nilai t hitung sebesar 2,144 dan nilai signifikansi sebesar 0,033. Oleh karena nilai signifikasi sebesar $0,033<0,05$, maka dapat disimpulkan bahwa Tingkat suku bunga berpengaruh terhadap Keputusan Penggunaan Fasilitas Pinjaman. Koefisien regresi bernilai positif menunjukkan bahwa pengaruh Tingkat suku bunga terhadap Keputusan Penggunaan Fasilitas Pinjaman bersifat searah.

Pesatnya pertumbuhan ekonomi dan bisnis baik di dunia atau di dalam negeri menjadikan bisnis perbankan tumbuh menjai beraneka ragam jenisnya.Bisnis perbankan ini mampu memberikan beraneka ragam pelayanan jasa ddengan berbagai fasilitas yang canggih.Perbankan sendiri merupakan perantara keuangan dari dua pihak yang melakukan transaksi keuangan.

Peningkatan perkembangan kegiatan dalam perekonomian atau perkembangan kegiatan usaha dari suatu perusahaan memerlukan sumber-sumber dana dari luat perusahaan untuk memberi biaya kepada perusahaan berkembang. Sumber dana yang berasal dari luar dapat diperoleh dengan melakukan pinjaman yang berasal dari bank yang mana disebut dengan kredit. 
Dengan kata lain, kredit adalah penyediaan uang atau tagihan yang dapat dipersamakan dengan itu, berdasarkan persetujuan atau kesepakatan pinjammeminjam antara bank dengan pihak lain yang mewajibkan pihak peminjam untuk melunasi utangnya setelah jangka waktu tertentu dengan pemberian bunga (Sembiring, 2014 : 149).

Banyaknya kondisi dimana yang dialami oleh perusahaan dengan tingkatan yang berbeda pada waktu dimana pembiayaan sendiri tidak akan cukup sehingga perusahaan memerlukan bantuan pembiayaan dalam bentuk kredit. Selain sebagai dana priduktif yang digunakan untuk usaha, kebutuhan dana masyarakat juga berkaitan dengan dana konsumtif yang akan digunakan untuk konsumsi yang akan digunakan untuk konsumsi.

Masyarakat butuh dalam penyaluran dana yang aman, cepat dan mudah sehingga dapat mengalihkan pinjaman ke bank dengan harapkan dapat memberikan dana segar dengan suku bunga yang rendah.Pengertian suku bunga Sunariyah (2013:80) adalah "harga dari pinjaman. Suku buna dinyatakan sebagai persentase uang pokok per unit waktu. Bunga merupakan suatu ukuran harga sumber daya yang digunakan oleh debitur yang harus dibayarkan kepada kreditur.

Suku bunga kredit merupakan salah satu hal penting yang menjadi pertimbangan masyarakat sebelum mereka memutuskan untuk mengajukan kredit pada Bank maupun lembaga keuangan non bank. Teori Keynes menyatakan bahwa suku bunga kredit berhubungan positif dengan jumlah penawaran kredit, yang artinya peningkatan suku bunga kredit dapat meningkatkan jumlah penawaran kredit, namun sebaliknya peningkatan suku bunga kredit dapat menurunkan jumlah permintaan kredit. Kenaikan tingkat suku bunga akan mengurangi keinginan baik untuk pinjaman kredit konsumsi maupun berinvestasi.

\subsubsection{Pengaruh Pelayanan Inti terhadap Keputusan Penggunaan Fasilitas Pinjaman}

Berdasarkan hasil olahan data diperoleh nilai t hitung sebesar 8,499 dan nilai signifikansi sebesar 0,000. Oleh karena nilai signifikasi sebesar 0,000<0,05, maka dapat disimpulkan bahwa Tingkat suku bunga berpengaruh terhadap Keputusan Penggunaan Fasilitas Pinjaman.

Seiring dengan perkembangan lembaga keuangan saat ini, seharusnya pihak lembaga keuangan tersebut dapat menerapkan strategi agar dapat menarik nasabah untuk menggunakan jasa keuangnya dengan memenuhi kebutuhan dan keingin yang nasabah inginkan sehingga lembaga keuangan tersebut harus meningkatkan kualitas pelayanan.

Tjipto (2010) kualitas pelayanan adalah tingkat keunggulan yang diharapkan dan pengendalian atas tingkat keunggulan tersebut untuk memenuhi keinginan pelanggan. Berdasarkan pendapat di atas dapat disimpulkan bahwa ada factor utama yang mempengaruhi kualitas pelayanan yaitu: Jasa yang diharapkan dan jasa yang dirasakan. Apabila jasa yang dirasakan sesuai dengan jasa yang diharapkan, maka kualitas pelayanan tersebut akan dipersepsikan baik atau positif. Jika jasa yang dipersepsikan melebihi jasa yang diharapkan, maka kualitas jasa 
dipersepsikan sebagai kualitas ideal. Demikian juga sebaliknya apabila jasa yang dipersepsikan lebih jelek dibandingkan dengan jasa yang dipersepsikan negative atau buruk. Maka baik tidaknya kualitas pelayanan tergantung pada kemampuan penyedia jasa dalam memenuhi harapan konsumen secara konsisten.

Terciptanya suatu kualitas pelayanan inti yang baik dan adanya citra positif dari bank maka akan dapat berdampak baik pada nasabah yang akan memutuskan dalam menggunakan jasa pada jasa perbankan. Kualitas inti merupakan penilaian konsumen terhadap kualitas layanan yang telahdiberikanolehsuatu perusahaan jasa dalam hal ini PT.Bank Rakyat Indonesia dan menjadi ciri barang atau jasa yang berhubungan langsung denganjasa yang akan digunakan dalam suatu bentuk yang nyata.Adanya pemberian kualitas pelayanan yang baik adalah agar konsumen merasakan kepuasan dan akan menjadi dampak positif untuk perusahaan perbankan. Dalam penelitian ini kualitas ini ditentukan berdasarkan proses pengajuan kredit nasabah pada PT Bank Rakyat Indonesia.

Sebelum mengetahui produk biasasanya calon nasabah menggali infomasi mengenai dengan jasa yang menyediakan pelayanan sesuai dengan apa yang diharapkan. Pelayanan inti yang diberikan tersebut dapat berkaitan dengan penggunaan jasa yang sama deng citra sehingga menimbulkan kesan positif untuk nasabah. Adanya infomasi mengenaik produk-produk akan menjadikan nasabah yakin untuk memutuskan penggunaan pada bank tersebut.

Strategi untuk memenangkan persaingan dalam bisnis perbankan terutama pada pinjaman yang diberikan oleh bank ini terletak pada pelayanan-pelayanan apa yang akan di berikan oleh bank serta fasilitas-fasilitas apa saja yang akan diberikan setelahnya sehingga nasabah dapat meminimalisir kerugian yang dialaminya. Pada zaman sekarang Fasilitas yang menarik dapat menjadikan acuan nasabah untuk tertarik menggunakan produk tersebut ditambah dengan kualitas layanan yang prima.

\subsubsection{Pengaruh Pelayanan Periferal terhadap Keputusan Penggunaan Fasilitas Pinjaman}

Berdasarkan hasil olahan data diperoleh nilai t hitung sebesar 2,179 dan nilai signifikansi sebesar 0,030. Oleh karena nilai signifikasi sebesar $0,030<0,05$, maka dapat disimpulkan bahwa Pelayanan Periferal berpengaruh terhadap Keputusan Penggunaan Fasilitas Pinjaman.

Adanya persaingan bisnis yang ketat antar bank di Indonesia ini memaksa dunia perbankan untuk mencari strategi guna memenangkan persaingan yang mana akan dapat meraih kesuksesan dalam dunia industri jasa perbankan. Salah satu untuk meraih kesuksesan dalam dunia perbankan ini dengan cara menciptakan kualitas pelayanan yang lebih baik daripada bank lainnya sehingga memberikan kesan menonjol yang dapat menarik perhatian calon nasabah.

Dengan memberikan pelayanan berupa letak lokasi yang strategis dan persyaratan mudah bagi nasabah akan dapat menimbulkan hal baik untuk nasabah. Parasuraman dalam Kheng et al. (2010) menyebutkan bahwa layanan berarti derajat perbedaan yang timbul dari proses pelayanan dan interaksi antara peyedia layanan dengan 
konsumen. Permasalahan mengenai layanan kini mendapat perhatian yang lebih besar dari banyak organisasi mulai dari organisasi regional, nasional sampai dengan organisasi global, dan dianggap sebagai alatyang dapat mempengaruhi arus pendapatan suatu organisasi atau perusahaan (Spohrer dan Maglio dalam Mosahab, 2010).

Selain itu, Parasuraman et al dalam Mosahab (2010) Kualitas pelayanan telah dikonseptualisasikan sebagai perbedaan antara harapan pelanggan mengenai pelayanan yang akan diterima dan persepsijasa yang diterima. Kualitas pelayanan merupakan sebuah konsep multidimensi.

Dalam penelitian ini kualitas periferal merupakan hal yang perlu di perlihatkan karena dapat menjadi strategi setelah pelayanan inti dalam persaingan antar bank.

Kualitas periferal merupakan penilaian konsumen terhadap suatu kualitas yang menyebabkan suatu barang atau jasa menjadi pilihan dan menjadi kualitas pendukung (Triupayanto, 2012: 90) :

\section{a. Fasilitas}

Sam (2012) Fasilitas adalah segala sesuatu yang berupa benda maupun uang yang dapat memudahkan serta memperlancar pelaksanaan suatu usaha tertentu.

b. Lokasi

Pemilihan lokasi berkaitan dengan komitmen jangka panjang terhadap aspek perusahaan. Heizer \& Render (2015) lokasi adalah pendorong biaya dan pendapatan, maka lokasi seringkali memiliki kekuasaan untuk membuat strategi bisnis perusahaan. Lokasi yang strategis bertujuan untuk memaksimalkan keuntugan dari lokasi perusahaan.

Dengan adanya kemudahan yang jauh lebih ringan yang diberikan oleh perbankan ini dapat membantu dalam pemberikan keputusan dalam penggunaan fasilitas pinjaman pada Bank BRI.Tentu saja dapat menarik perhatian nasabah dengan jauh lebih mudah apabila terdapat factor-faktor dimana lokasi dan fasilitas yang diutamakan dalam menjalin kerjasama.

\subsubsection{Pengaruh Tingkat Suku Bunga, Pelayanan Inti dan Pelayanan Periferal terhadap Keputusan Penggunaan Fasilitas Pinjaman}

Dari hasil pengujian regresi menunjukkan pengujian simultan diperoleh dari hasil pengolahan data menunjukkan nilai $\mathrm{F}$ hitung sebesar 60,580 dan nilai probabilitas signifikansi tersebut sebesar 0,000 dan tingkat $\alpha$ sebesar $5 \%$, hal ini menunjukkan bahwa nilai signifikansi uji F 0,000 lebih kecil daripada nilai signifikansi 0,05. Artinya bahwa Tingkat suku bunga (X1), Pelayanan Inti (X2), dan Pelayanan Periferal (X3) merupakan penjelas nyata terhadap Keputusan Penggunaan Fasilitas Pinjaman. Dengan kata lain model penelitian layak digunakan.

Melihat keberadaan dunia perbankan secara umum zaman sekarang ini memiliki fungsi yang strategis dalam menjadi lembaga intermediasi serta pemberian layanan jasa.Adanya karakteristik yang diberikan oleh bank ini dapat mempengaruhi keputusan calon nasabah dalam menjalin kerjasama. Karakteristik yang berikan oleh bank ini berubah pelayanan yang berupa fasilitas-fasilitas apa saja yang ditawarkan oleh dunia 
perbankan. Usaha yang dilakukan oleh dunia perbankan sangatlah sengit sehingga harus berlomba-lomba dalam memenuhi keinginan nasabah agar membawa dampak positif untuk nasabah dimana akan mempunyai banyak pilihan jasa perbankan yang akan dipilih.

Setiap bank umum nya ingin mempertahankan eksistensinya sehingga dapat terus berkembang dan akan mengalami kemajuan dalam dunia bisnis berpankan sehingga harus benar dalam memenuhi keinginan dan kebutuhan nasabah hingga ingin memutuskan dalam penggunaan fasilitas yang telah di tawarkan oleh bank yang mana terdapat fasilitas pinjaman untuk nasabah atau kredit.

Adapun alasan mengapa seseorang memerlukan kredit yaitu karena manusia adalah Homo Economicus yang dimana setiap manusia akan selalu berusaha untuk memenuhi kebutuhannya. Dengan sumber daya atau kemampuan yang dimiliki manusia yang terbatas untuk memenuhi kebutuhan atau keinginan yang tidak terbatas, hal ini menyebabkan manusia memerlukan bantuan modal untuk memenuhi kebutuhan atau keinginannya yang tak terbatas.

Pemberian suatu fasilitas kredit ini mempunyai tujuan yaitu tidak terlepas dari misi bank tersebut saat didirikan, adapun tujuan utama dalam pemberian kredit ini yaitu untuk mencari keuntunfan dalam membantu nasabah dan pemerintahan. Hal ini di dukung oleh Kasmir (2013:94) adalah mencari keuntungan, membantu nasabah dan membantu pemerintah.

Keputusan nasabah dalam mengambil kredit merupakan pemilihan dari dua atau lebih alternatif pilihan keputusan pengambilan kerdit, artinya bahwa nasabah dapat membuat keputusan dalam mengambil kredit mempunyai alternatif lainnya.Keputusan nasabah dalam mengambil kredit, sangat penting sebelum nasabah mengambil kredit pada bank.Keputusan bermaksud agar tidak adanya hambatan baik yang besa maupun yang kecil sehingga perlu diambil suatu keputusan sehingga saat mengambil keputusan harus cermat dan sesuai tujuan yang telah direncanakan sebelumnya (Kuncoro \& Adhitya, 2010).

Salah satu yang dapat menjadi daya tarik dalam pengambilan keputusan nabah dalam penggunaan fasilitas pinjaman Bank BRI yaitu tingkat suku bunga, pelayanan inti dan pelayanan peripheral. Tingkat suku bunga merupakan salah satu indikator dalam menentukan apakah seseorang akan melakukan investasi atau menabung (Boediono, 2014:76).

Salah satu hal penting yang menjadi pertimbangan masyarakat sebelum mereka memutuskan untuk mengajukan kredit pada Bank maupun lembaga keuangan non bank yaitu suku bunga kredit. Teori Keynes menyatakan bahwa suku bunga kredit berhubungan positif dengan jumlah penawaran kredit, yang artinya peningkatan suku bunga kredit dapat meningkatkan jumlah penawaran kredit, namun sebaliknya peningkatan suku bunga kredit dapat menurunkan jumlah permintaan kredit. Kenaikan tingkat suku bunga akan mengurangi keinginan baik untuk pinjaman kredit konsumsi maupun berinvestasi.

Selain itu, Parasuraman et al dalam Mosahab (2010) Kualitas pelayanan telah dikonseptualisasikan sebagai perbedaan antara harapan pelanggan mengenai 
pelayanan yang akan diterima dan persepsijasa yang diterima. Kualitas pelayanan merupakan sebuah konsep multidimensi. Dalam penelitian ini kualitas pelayanan dibagi menjadi dua yaitu kualitas pelayanan inti dan kualitas pelayanan peripheral.

Kualitas inti merupakan penilaian konsumen terhadap kualitas layanan yang telahdiberikanolehsuatu perusahaan jasa dalamhaliniPT.BankRakyat Indonesiadan menjadi ciri barang atau jasa yang berhubungan langsung denganjasa yang akan digunakan dalam suatu bentuk yang nyata. Dengan adanya kualitas pelayanan inti yang baik ini akan menjadikan konsumen merasakan kepuasan dan akan memberikan dampak positif untuk perusahan bank tersebut. Dalam penelitian ini dapat ditentukan dengan proses pengajuan kredit nasabah pada PT Bank Rakyat Indonesia.

Keputusan penggunaan fasilitas pinjaman Bank BRI ini diperkuat dengan adanya kualitas periferal.Kualitas periferal merupakan penilaian konsumen terhadap suatu kualitas yang menyebabkan suatu barang atau jasa menjadi pilihan dan menjadi kualitas pendukung Triupayanto (2012: 90) yaitu fasilitas dan lokasi. Hal tersebut diharapkan dapat memenuhi keinginan nasabah dalam mengambil keputusan fasilitas pinjaman Bank BRI.

\section{PENUTUP}

\subsection{Kesimpulan}

Dari hasil dan pembahasan maka dapat disimpulkan bahwa :

Tingkat suku bunga, kualitas pelayanan inti dan kualitas pelayanan periferal berpengaruh terhadap keputusan penggunaan fasilitas kredit Bank BRI pada karyawan PDAM Cabang Bekasi, dengan pengaruh terbesar ditunjukan oleh kualitas pelayanan inti.

\subsection{Saran}

Adapun saran dalam penelitian ini adalah:

1. Bank BRI disarankan untuk meningkatkan suku bunga, kualitas pelayanan inti dan kualitas pelayanan peripheral terhadap keputusan penggunaan fasilitas pinjaman bank.

2. Kepada peneliti Selanjutnya diharapkan dapat melakukan penelitian lanjutan tentang keputusan penggunaan fasilitas pinjaman bank, karena masih banyak factor lain yang dapat mempengaruhi keputusan penggunaan fasilitas pinjaman bank BRI sepertitingkat suku bunga, kualitas pelayanan inti dan kualitas pelayanan periferal.

\section{DAFTAR PUSTAKA}

Augusty Ferdinand. 2011, Metode Penelitian Manajemen Pedoman Penelitian untuk Penulisan Skripsi, Tesis, dan Disertasi Ilmu Manajemen, Edisi 3, AGF Books, Fakultas Ekonomika dan Bisnis Universitas Diponegoro, Semarang.

Basu Swasta dan T. Hani Handoko, 2008, Manajemen Pemasaran, Analisa Perilaku Konsumen, edisi pertama, cetakan keempat, Penerbit : BPFE, Yogyakarta 
Daradjat, Zakiah. Dkk. 2008. Ilmu Pendidikan Al Quran, Jakarta: PT. Bumi Aksara

Fandy, Tjiptono. 2011. Service Management Mewujudkan Layanan Prima. Edisi 2. Yogyakarta: Andi.

Firtianto, Hadi. 2010. Keputusan Permintaan Kredit Kepemilikan Rumah (KPR) pada Bank BTN Cabang Malang. Yogyakarta: Fakultas Ekonomi dan Bisnis Universitas Gajah Mada .

Ghozali, Imam. 2011. "Aplikasi Analisis Multivariate Dengan Program SPSS". Semarang: Badan Penerbit Universitas Diponegoro.

Ghozali, Imam. 2013. Aplikasi Analisis Multivariate dengan Program IBM SPSS 21 Update PLS Regresi. Semarang: Badan Penerbit Universitas Diponegoro.

Heizer, Jay and Render Barry, (2015), Manajemen Operasi : Manajemen Keberlangsungan dan Rantai Pasokan, edisi 11, Salemba Empat, Jakarta.

Kasmir. 2012. Bank dan Lembaga Kuangan Lainnya. Jakarta: PT. Raja Grafindo Persada.

Kasmir. 2013. “Analisis Laporan Keuangan”. Edisi 1. Cetakan ke-6. Jakarta: Rajawali Pers.

Kheng, Lo Liang, et.al. 2010. "The Impact of Servive Quality on Customer Loyalty : A study of Bank in Penang, Malaysia”. International Journal of Marketing Studies. Vol, No. 2 (November 2010), Hal 57-66.

Kotler, Philip \& Garry Armstrong. 2010. Prinsip-Prinsip Pemasaran, Jilid 1 dan 2 Edisi Kedua Belas. Jakarta : Erlangga

Kotler, Philip and Gary Amstrong. (2016). Prinsip-prinsip Pemasaran. Edii13. Jilid 1. Jakarta:Erlangga

Kotler, Philip dan Amstrong, Gary, (2014), Principles of Marketin, $12^{\text {th }}$ Edition, Jilid 1 Terjemahan Bob Sabran Jakarta : Erlangga.

Kuncoro, Engkos ahmad dan Adithya Wiranegara (2010), Pengaruh Promosi dan Atribut produk terhadap Keputusan Pembelian pada Produk Telkom Speedy, Jurnal Manajemen Ikatan Sarjana Ekonomi Indonesia (I.S.E.I), volume 1 nomor 2 pp. 132 - 145

Lupiyoadi, Hamdani. 2006. Manajemen Pemasaran Jasa, Edisi Kedua. Jakarta : Penerbit Salemba Empat.

Lupiyoadi, Rambat. 2013. Manajemen Pemasaran Jasa Berbasis Kompetensi (Edisi 3). Jakarta: Salemba Empat.

Mishkin, Frederic S. 2008. Ekonomi Uang, Perbankan, dan Pasar Keuangan. Edisi 8. Salemba Empat : Jakarta.

Mosahab, Rohim, et al. 2010. Service Quality, Customer Satisfaction and Loyalty: A Test of Mediation. International Basiness Research Journal. VO1. 3 No. 4 Page $72-80$

Munawaroh, Munjiati. (2013). Manajemen Operasi. Yogyakarta. LP3M UMY.

Sembiring, J.; Suharyono; Kusumawati, A. (2014), Pengaruh Kualitas Produk Dan Kualitas Pelayanan Terhadap Kepuasan Pelanggan Dalam Membentuk Loyalitas Pelanggan. Jurnal Administrasi Bisnis, 15 (1) : 1 - 10

Sentosa Sembiring, (2012) Hukum Perbankan Edisi Revisi, Mandar Maju, Bandung. 
Sugiyono. (2013). Metode Penelitian Kuantitatif, Kualitatif dan R\&D. Bandung: Alfabeta.CV

Sunariyah.2013. Pengantar Pengetahuan Pasar Modal (Edisi 6).Penerbit : UPP STIM YKPN, Yogyakarta.

Tjiptono, Fandy. 2010, Strategi Pemasaran, Edisi 2, Andi Offset, Yogyakarta.

Triupayanto, Ajhiyang Pangandel. (2012). Analisis Pengaruh Kualitas Pelayanan Inti dan Kualitas Pelayanan Periferal Melalui Kepuasan Konsumen Pada Minat Mereferensikan Jasa Pengguna Jasa Lapangan Futsal. Skripsi, Fakultas Ekonomi, Program Sarjana Universitas Diponegoro. Semarang.

Undang-Undang No. 10 Tahun 1998 Tentang Perubahan atas Undang-Undang No. 7 Tahun 1992 Tentang Perbankan

Widiyanto, M.A (2013). Statistika Terapan, Jakarta : PT Elex Media Komputindo

Zulfikar., 2016., Pengantar Pasar Modal Dengan Pendekatan Statistika Edisi Pertama, Cetakan Pertama, Gramedia, Yogyakarta

Zulian, Yamit, 2010, Manajemen Kualitas Produk \& Jasa, Vol. Edisi Pertama, EKONISIA, Yogyakarta. 